\title{
Pharmacology activities and extraction of $\alpha$-chitin prepared from crustaceans: A review
}

\author{
Renny Amelia ${ }^{1,2^{*}}$, Nyi Mekar Saptarini ${ }^{3}$, Eli Halimah², Yuli Andriani ${ }^{4}$, Aliya Nurhasanah ${ }^{3}$, Jutti Levita ${ }^{2}$, Sri Adi Sumiwi ${ }^{2}$ \\ ${ }^{1}$ Department of Pharmacology, School of Pharmacy Muhammadiyah Cirebon, Cirebon, Indonesia. \\ ${ }^{2}$ Department of Pharmacology and Clinical Pharmacy, Faculty of Pharmacy, Universitas Padjadjaran West Java, Indonesia. \\ ${ }^{3}$ Department of Pharmaceutical Analysis and Medicinal Chemistry, Faculty of Pharmacy, Universitas Padjadjaran, West Java, Indonesia. \\ ${ }^{4}$ Faculty of Fisheries and Marine Sciences, Universitas Padjadjaran, West Java, Indonesia.
}

\section{ARTICLE INFO \\ Received on: $12 / 06 / 2020$ \\ Accepted on: 23/09/2020 \\ Available online: 05/12/2020}

Key words:

$\alpha$-chitin, extraction, anti-

inflammatory, anticancer,

NADES, crab, glucosamine,

marine.

\begin{abstract}
Most crustacean shells are not utilized and are discarded to become waste. $\alpha$-Chitin, a polysaccharide compound, is commonly found in crustaceans shells. This polysaccharide is widely used in agriculture, pharmacy, and industry. Our review aims to add insights into various methods for extracting chitin from crustaceans. Besides, the pharmacological activities of $\alpha$-chitin are also discussed in this article. The method of finding data was sourced from PubMed with predetermined criteria. From the article search, it was obtained that there are several ways to extract $\alpha$-chitin from crustaceans, namely the chemical method, the microbiological method, and the combination of the chemical and enzymatic methods. The pharmacology activities of $\alpha$-chitin from crustaceans, in general, revealed its potential to be developed as anticancer and anti-inflammatory and to accelerate wound healing.
\end{abstract}

\section{INTRODUCTION}

Chitin, a homopolysaccharide structure arranged over $\mathrm{N}$-acetyl-D-glucosamine molecules connected by the $\beta(1 \rightarrow 4)$ glycosidic bonds, is the second largest compound after cellulose. This colorless, crystalline, or amorphous powder is insoluble in water, organic solvents, dilute acids, and bases (Mathur and Narang, 1990).

Chitin occurs in three different polymorphisms isomers $(\alpha, \beta$, and $\gamma)$ where $\mathrm{N}$-acetyl glycosyl is a crystallographic unit that is common in all forms (Agboh and Qin, 1997). The intermolecular bonds in chitin are arranged like sheets. The bond that presents in one sheet possesses the same orientation "sense"; for example, in $\beta$-chitin, the sheets along the c-axis point in the same direction and the arrangement between the sheets is also parallel. In $\alpha$-chitin, the

\section{*Corresponding Author}

Renny Amelia, Department of Pharmacology, School of Pharmacy Muhammadiyah Cirebon, Cirebon, Indonesia; Department of Pharmacology and Clinical Pharmacy, Faculty of Pharmacy, Universitas Padjadjaran West Java, Indonesia.E-mail: rennyamelia@stfmuhammadiyahcirebon.ac.id sheets along the c-axis face the opposite direction (antiparallel) to that of the $\beta$-chitin. In $\gamma$-chitin, every third sheet has an opposite direction compared to those of the previous two sheets (Aranaz et al., 2009; Roy et al., 2017).

Compared to $\beta$-chitin, the $\alpha$-chitin form is more widely available in nature. Cuttlefish bone is an example of a source of $\beta$-chitin (Jung et al., 2018), but the $\beta$-chitin form will change into the $\alpha$-chitin form when it undergoes an excessive deacetylation process using alkaline and acidic solvents (Akpan, 2018). In nature, $\alpha$-chitin occupies the most amount compared to other polymorphic forms (Maruthiah and Palavesam, 2017). $\alpha$-Chitin can be found in the sponge (Tarusin et al., 2017), crab (Ifuku et al., 2009), shrimp (Goodrich and Winter, 2007), (Aranaz et al., 2009), insect cuticles (Wu et al., 2020), fungi (Hassainia et al., 2018), and sea snail (Mohan et al., 2019). Of these various sources, most of the industries prefer using crustaceans subphylum in the manufacture of $\alpha$-chitin. Crustaceans are available in an abundant amount, as recorded globally in 2017 that almost 15.2 million tons of crustaceans had been produced (FAO, 2020). Parts of the shells, claws, heads, and other wasted parts of the crustaceans can reach $70 \%$ of the total weight of these sea creatures. Little can be used 
as animal feed and fertilizer, while the majority of the remainder is discarded (Ordóñez-Del Pazo et al., 2014). This huge amount of waste could affect the global sea pollution; thus, a further process should be undertaken knowing that chitin contained in crustacean waste has a higher amount (approximately 20\%-30\%) than other species (Vani et al., 2013).

There are two important steps in chitin extraction, for example, deproteination and demineralization. Sometimes an additional step needs to be carried out, that is, decolorization. Currently, the chitin extraction process is growing. Chitin extraction was first carried out using alkali and acids; however, lately, many researchers prefer to employ chemical, enzymatic, microbiological (Bajaj et al., 2015), and natural deep eutectic solvents (NADES) and several other methods.

The existence of chitin is now most preferable because it is biocompatible, biodegradable, easily absorbed in tissues, and nontoxic to both humans and the environment. Its functions are very broad which include in pharmacy, biomedical food, textile, packaging, agriculture, and others (Aranaz et al., 2009; Jollès and Muzzarelli, 1999; Roy et al., 2017). To the best of our knowledge, no existing article has reviewed the pharmacological activities of $\alpha$-chitin sourced from the subphylum crustaceans. Therefore, this article aims to focus on the up-to-date extraction methods and the pharmacological activities of $\alpha$-chitin from crustaceans.

\section{METHODS}

Articles were obtained from the PubMed database by inputting strategies, population (P) (crustacean); intervention (I) (preparation; extraction); control (C) ( $\alpha$-chitin; chitin); outcome (O) (chitin yield, demineralization, deproteination, and pharmacology effect); MeSH: ("Chitin/analysis" [MeSH] or "Chitin/biosynthesis" [MeSH] or "Chitin/pharmacology" [MeSH] and "Crustaceans" [MeSH]) NOT "Chitosan" [MeSH]. Chitin derivatives and chitin other than the crude form, for example, chitin nanofibers, chitin nanocrystal, nanochitin, and other forms of chitin, which have undergone further processes besides demineralization, deproteination, and decolorization, were excluded from the search. The search was carried out on all articles published with the above keywords until April 2020.

\section{Extraction process}

Every sea species that contains chitin is always associated with organic and inorganic substances, which affect its amount. Processes and conditions during extraction also affect the amount of chitin produced (Sorokulova et al., 2009). Deproteination and demineralization steps are considered as critical, due to its role in removing the protein, minerals, lipids, and pigments (Hamdi et al., 2017). Some extraction processes prioritize the demineralization process. However, it is not uncommon that deproteination takes precedence in eliminating some minerals by breaking up the calcium-protein-chitin complex in skeletal tissues during fermentation (Zhang et al., 2012). Before extraction, the shell should be boiled to make it easier to clean the shell from the remaining meat. The rest of the meat must be removed immediately to avoid the occurrence of the odor (Xu et al., 2008). The boiling process is also intended to reduce protease activity with the aim of chitin purification (Flores-albino et al., 2012). Figure 1 shows the process of all extractions.

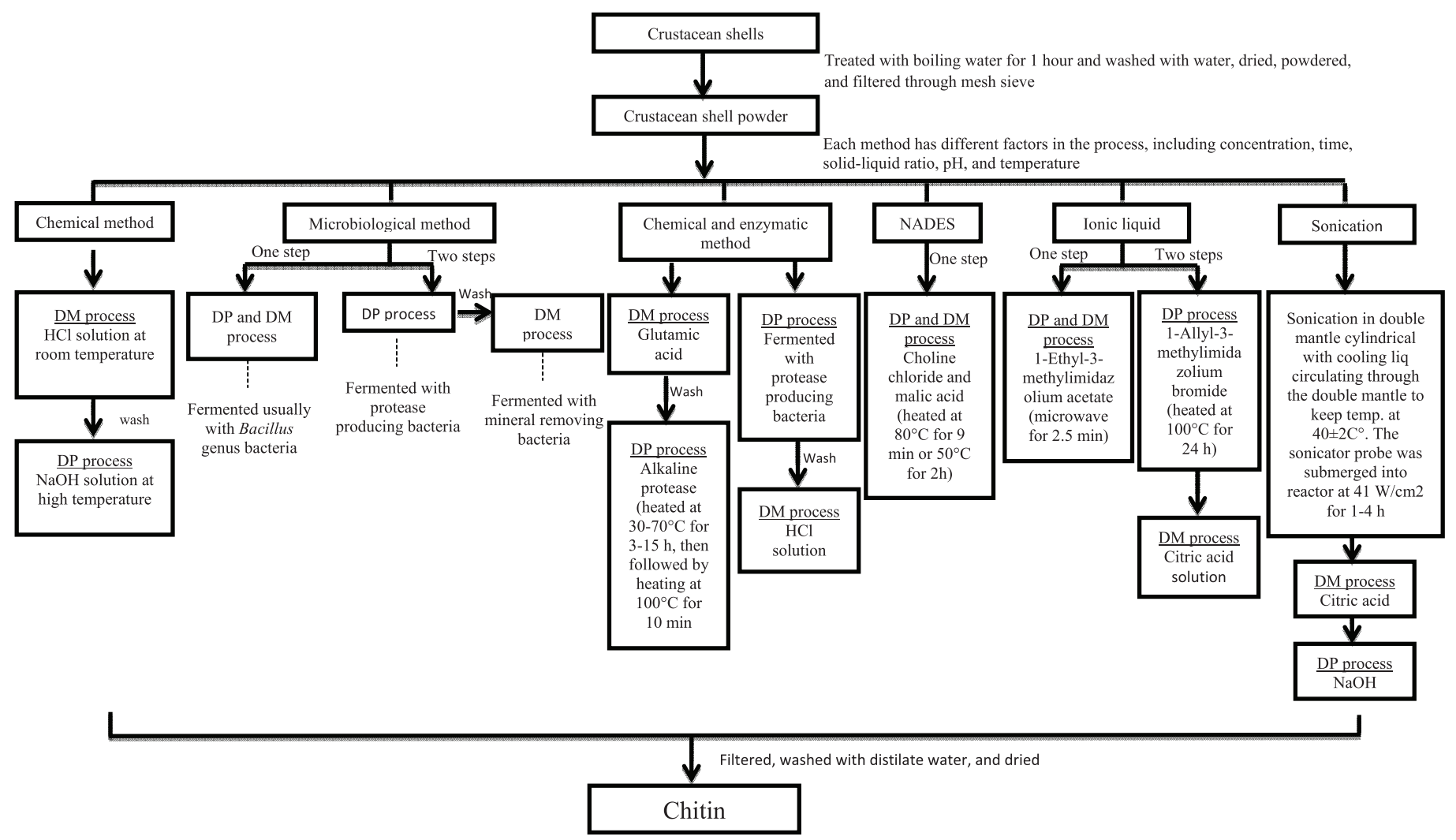

Figure 1. Chitin extractions with various methods. ${ }^{*} \mathrm{DM}=$ demineralization; $\mathrm{DP}=$ deproteination. 


\section{Chemical extraction method}

Chemical extraction generally employs alkaline and acidic solvents at high temperatures during the deproteination process (Younes et al., 2014). In general, the conditions during the extraction process will greatly affect the molecular weight and the degree of chitin acetylation. The disproportionate time, $\mathrm{pH}$, and temperature during demineralization will produce chitin with a lower molecular weight. Chitin is a sensitive acid compound and can be degraded through several pathways. Hydrolytic depolymerization, heat degradation, and deacetylation are some of the pathways that will cause the physiological properties of the final product to be inconsistent (Ghorbel-Bellaaj et al., 2013; Sorokulova et al., 2009; Younes et al., 2012). Extraction using alkalis and acids produces waste that contains a lot of chloride, sodium, and calcium ions that are difficult to degrade, which will be a problem for the environment (Ding et al., 2020; GhorbelBellaaj et al., 2013).

The deproteination process produces hydrolyzed protein waste, a hydrolysis solution of protein that is rich in amino acids, peptides, and chitooligosaccharides (Rinaudo, 2006). Hydrolyzed protein from chemical extraction deproteination cannot be used because it contains dangerous alkali solvents (Younes et al., 2014). Another disadvantage is that it consumes energy and produces large amounts of corrosive alkaline acids and can damage the environment (Ghorbel-bellaaj et al., 2013). However, chemical extraction methods produce a consistent amount of chitin and short time extraction (Kaya et al., 2014).

\section{Microbiological extraction method}

Given the various limitations of chemical extraction, the researchers keep looking for a safer, environment-friendly, green extraction that could produce more chitin in higher quality. One of the environment-friendly biotechnology methods is the fermentation using lactic acid bacteria (LAB). During fermentation, the bacteria will convert carbon sources, such as glucose or molasses, into lactic acid and $\mathrm{pH}$ will decrease due to the production of lactic acid. Crustacean shells have calcium carbonate and will react with lactic acid to form calcium lactate
(Mao et al., 2013) The acid produced will be responsible for the demineralization process.

The presence of glucose or other carbon sources becomes a critical point that will determine the level of efficiency of the demineralization process (Ghorbel-Bellaaj et al., 2012). Although high glucose concentrations will accelerate the fermentation cycle, fermentation will be inhibited and $\mathrm{pH}$ will increase when the sugar concentration exceeds 15\% (Zhang et al., 2012). Glucose at a concentration of $5 \%$ can induce protease production even up to four times more than the medium that does not use glucose (Ghorbel-Bellaaj et al., 2012).

The use of protease enzymes in the chitin extraction process will facilitate the removal of protein and calcium carbonate. Bacteria were tested first before use to see the ability to produce proteases. The test was continued to see the activity of proteolysis, for example, by looking at the proteolytic zone of casein agar (Harkin et al., 2015). The use of protease or lactic acid produced by bacteria to extract chitin is simple and inexpensive (Ghorbel-bellaaj et al., 2013).

The deproteination and demineralization can be either done simultaneously or carried out separately into two steps (Dun et al., 2019). Two-step fermentation has the advantage of acquiring chitin with a high grade of purity. LAB and proteaseproducing microbials have different optimal growth conditions so that it is preferably carried out in two steps. However, the two-step fermentation process requires a longer time and higher costs (Xu et al., 2008). The fermentation process that includes deproteinizing or demineralizing can be carried out in one step. However, the efficiency of deproteination is difficult to achieve; therefore, optimization of the factors that influence the process of demineralization and deproteination is needed (Oh et al., 2007).

Many factors will influence the demineralization and deproteination processes, such as carbon source and glucose concentration, inoculum amount, $\mathrm{pH}$, and fermentation time (Arbia et al., 2013) so that several methods of approach for optimization studies in extracting chitin can be used, such as the Box-Behnken design or the Plackett-Burman design. These methods are also useful for understanding interactions between various physicochemical parameters using a minimum number of

Table 1. Various reports on $\alpha$-chitin extraction using the chemical method.

\begin{tabular}{|c|c|c|c|c|c|c|c|c|c|c|}
\hline \multirow{2}{*}{ No. } & \multirow{2}{*}{ Crustacean } & \multicolumn{3}{|c|}{ Demineralization } & \multicolumn{3}{|c|}{ Deproteination } & \multirow{2}{*}{ Note } & \multirow{2}{*}{$\begin{array}{c}\text { Chitin yield } \\
(\%)\end{array}$} & \multirow{2}{*}{ Reference } \\
\hline & & $\mathrm{HCl}(\mathrm{w} / \mathrm{v})$ & Time & $\mathbf{T}\left({ }^{\circ} \mathbf{C}\right)$ & $\mathrm{NaOH}(\mathrm{w} / \mathrm{v})$ & Time & $\mathbf{T}\left({ }^{\circ} \mathrm{C}\right)$ & & & \\
\hline 1. & Chilean crab & $2 \mathrm{~N} \mathrm{HCl}(1: 10)$ & 1 hours & Room & $1 \mathrm{M} \mathrm{NaOH}(1: 20)$ & 3 hours & 100 & - & 10,4 & (Bernabé et al., 2020) \\
\hline 2. & Lobster & $\mathrm{HCl} 6 \%$ & 2.5 hours & Room & $\mathrm{NaOH} 10 \%$ & 3 hours & 90 & $\begin{array}{c}\text { Decolorize: } \\
\mathrm{H} 2 \mathrm{O} 210 \% \text { at } \\
80^{\circ} \mathrm{C}\end{array}$ & $16.53 \pm 2.3$ & (Zhu et al., 2017) \\
\hline 3. & Barnacle (Chelonibiapatula) & $1 \mathrm{M} \mathrm{HCl}$ & 10 minutes & Room & $2 \mathrm{M} \mathrm{NaOH}$ & 20 minutes & - & - & 3.11 & (Kaya et al., 2014) \\
\hline 4. & $\begin{array}{l}\text { Shrimp(Metapenaeus } \\
\text { monoceros) }\end{array}$ & $\begin{array}{c}1.25 \mathrm{M} \mathrm{HCl} \\
(1: 10)\end{array}$ & 6 hours & Room & $1.25 \mathrm{M} \mathrm{NaOH}$ & 4 hours & - & - & $20 \pm 2$ & (Manni et al., 2010) \\
\hline 5. & $\begin{array}{l}\text { Shrimp (Parapenaeopsis } \\
\text { stylifera) }\end{array}$ & $0.25 \mathrm{M} \mathrm{HCl}$ & $\begin{array}{l}15 \text { minutes } \\
(1: 40)\end{array}$ & Room & $1 \mathrm{M} \mathrm{NaOH}(1: 30)$ & 24 hours & 70 & $\begin{array}{l}\text { DP: } 98 \% \\
\text { DM: } 90 \%\end{array}$ & - & (Percot et al., 2003) \\
\hline 6. & Krill (Euphausia superba) & $1.7 \mathrm{M} \mathrm{HCl}$ & 6 hours & Room & $2.5 \mathrm{M} \mathrm{NaOH}$ & 1 hours & 75 & $\begin{array}{l}\text { Decolorization: } \\
1 \% \text { potassium } \\
\text { permanganate }\end{array}$ & $27.80 \pm 1.48$ & (Wang et al., 2013) \\
\hline
\end{tabular}

*DM = demineralization;

$\mathrm{DP}=$ deproteination 
Table 2. $\alpha$-Chitin extraction using microbial fermentation with demineralization and deproteination yield.

\begin{tabular}{|c|c|c|c|c|c|c|}
\hline No. & Crustacean & Microbial & Fermentation process & $\% \mathrm{DM}$ & $\%$ DP & Reference \\
\hline \multirow[t]{3}{*}{1.} & Shrimp & Paracoccus saliphilus & $\begin{array}{l}\text { Shell powder mixed with halophilic production } \\
\text { medium (1:3). After sterilized, } 5 \% \text { Paracoccus }\end{array}$ & - & 85.64 & (Maruthiah and Palavesam, 2017) \\
\hline & Crab & & $\begin{array}{l}\text { saliphilus was inoculated into the media at } 50^{\circ} \mathrm{C} \\
\text { for } 3 \text { hours }\end{array}$ & - & 69.33 & \\
\hline & Lobster & & & - & 40.18 & \\
\hline 2. & Shrimp & Bacillus subtilis & $\begin{array}{l}\text { Using Box-Behnken design, the optimum value } \\
\text { will be obtained with conditions: sucrose }(5 \%) \text {, } \\
\text { shrimp shell }(12.5 \%) \text {, inoculum size }(10 \%) \text {, and } \\
\text { fermentation time ( } 7 \text { days) }\end{array}$ & 82.1 & 96.0 & (Gamal et al., 2016) \\
\hline 3. & $\begin{array}{l}\text { Shrimp (Penaeus } \\
\text { merguiensis) }\end{array}$ & $\begin{array}{l}\text { Pseudomonas aeruginosa, Serratia } \\
\text { marcescens, and Bacillus pumilus }\end{array}$ & $\begin{array}{l}\text { Three proteases producing bacteria mixed with } \\
5 \% \text { shrimp shell and } 10 \% \text { glucose fermented at } \\
60^{\circ} \mathrm{C} \text { for } 6 \text { days }\end{array}$ & 78.46 & 74.76 & (Sedaghat et al., 2016) \\
\hline \multirow[t]{6}{*}{4.} & \multirow{6}{*}{$\begin{array}{l}\text { Crab (Carcinus } \\
\text { mediterraneus) }\end{array}$} & B. subtilis & \multirow{6}{*}{$\begin{array}{l}\text { Crab shell was fermented into medium with } 5 \% \\
\text { glucose, at } 37^{\circ} \mathrm{C} \text { for } 5 \text { days using protease- } \\
\text { producing bacteria }\end{array}$} & 76.7 & 81.6 & \multirow[t]{6}{*}{ (Hajji et al., 2015) } \\
\hline & & Bacillus mojavensis & & 73.2 & 80.4 & \\
\hline & & B. pumilus & & 83.07 & 95 & \\
\hline & & Bacillus amyloliquefaciens & & 79.8 & 85.3 & \\
\hline & & Bacillus licheniformis & & 89 & 92 & \\
\hline & & Bacillus cereus & & 81.8 & 83.1 & \\
\hline 5. & $\begin{array}{l}\text { Shrimp (Metapenaeus } \\
\text { monoceros) }\end{array}$ & B. pumilus & $\begin{array}{l}\text { Using Plackett-Burman design, the optimum } \\
\text { value will be obtained with conditions: shrimp } \\
\text { shell }(70 \mathrm{~g} / \mathrm{l}) \text { and } 5 \% \text { glucose sol fermented, } \mathrm{pH} \\
\text { of } 5.0 \text {, at } 35^{\circ} \mathrm{C} \text { for } 6 \text { days }\end{array}$ & 88 & 94 & (Ghorbel-bellaaj et al., 2013) \\
\hline \multirow[t]{6}{*}{6.} & \multirow{6}{*}{$\begin{array}{l}\text { Shrimp (Metapeneaus } \\
\text { monoceros) }\end{array}$} & B. pumilus & \multirow{6}{*}{$\begin{array}{l}\text { Fermentation is done by adding shrimp shell } \\
\text { in } 5 \% \text { glucose medium. After sterilization, the } \\
\text { medium was fermented with each microbial for } \\
5 \text { days at } 37^{\circ} \mathrm{C}\end{array}$} & 75.3 & 91.2 & \multirow[t]{6}{*}{ (Ghorbel-Bellaaj et al., 2012) } \\
\hline & & B. mojavensis & & 78.7 & 88 & \\
\hline & & B. licheniformis & & 55.55 & 90.8 & \\
\hline & & B. cereus & & 77.3 & 88.6 & \\
\hline & & B. amyloliquefaciens & & 66.05 & 90.8 & \\
\hline & & B. subtilis & & 79.9 & 91.25 & \\
\hline 7. & $\begin{array}{l}\text { Shrimp (Penaeus } \\
\text { vannamei) }\end{array}$ & Lactobacilllus acidophilus & $\begin{array}{l}\text { Shrimp shell, microbial, and glucose were } \\
\text { fermented at } 37^{\circ} \mathrm{C} \text { for } 96 \text { hours }\end{array}$ & 99.5 & 97.4 & (Duan et al., 2012) \\
\hline 8. & $\begin{array}{l}\text { Shrimp (Metapeneaus } \\
\text { monoceros) }\end{array}$ & P. aeruginosa & $\begin{array}{l}\text { Using the Plackett-Burman design, shrimp } \\
\text { shell and } 5 \% \text { glucose }(1: 1) \text { were fermented with } \\
\text { microbial for } 5 \text { days }\end{array}$ & 96 & 89 & (Ghorbel-Bellaaj et al., 2011a) \\
\hline \multirow[t]{2}{*}{9.} & \multirow[t]{2}{*}{ Shrimp } & B. cereus & \multirow{2}{*}{$\begin{array}{l}\text { Shrimp shell } 3 \% \text { was fermented with inoculum } \\
\text { microbial } 10 \% \text { for } 14 \text { days at } 37^{\circ} \mathrm{C}\end{array}$} & 95 & 92 & \multirow[t]{2}{*}{ (Sorokulova et al., 2009) } \\
\hline & & Exiguobacteriumacetylicum & & 97.1 & 92.8 & \\
\hline 10. & $\begin{array}{l}\text { Red crab (Chionoecetes } \\
\text { japonicus) }\end{array}$ & $\begin{array}{l}\text { Lactobacillus paracasei subsp. } \\
\text { Tolerans and S. marcescens }\end{array}$ & $\begin{array}{l}\text { Crab shell with } 10 \% \text { glucose and microbial was } \\
\text { added and fermented at } 30^{\circ} \mathrm{C} \text { for } 7 \text { days }\end{array}$ & 97.2 & 52.6 & (Jung et al., 2006) \\
\hline
\end{tabular}

*DM $=$ demineralization;

$\mathrm{DP}=$ deproteination

experiments. The Plackett-Burman design aims to select important factors from a large number of variables. From many important factors, there will then be tested statistics where this will be useful in designing experiments, building models, and evaluating the effects of different factors to find the optimal conditions for getting chitin (de Coninck et al., 2000; Ghorbel-Bellaaj et al., 2011).

In general, an enzymatic process using bacteria is carried out by the fermentation process. High protease activity shows the ability to hydrolyze protein more and more (Sedaghat et al., 2016). Most of the microbes used are free of chitinolytic activity which prevents the reduction of chitin quality during deproteination (Bajaj et al., 2015). Deproteination cannot reach 100\%; this is because the enzyme does not get access to penetrate some of the protected proteins in the innermost layer, and ultimately proteolysis will not occur (Wang et al., 2006). The result of obtaining chitin by this method is chitin which has molecular weight and crystalline which is higher than chemically prepared chitin (Pacheco et al., 2011). The other disadvantage of microbial extraction is that it takes a long time. In general, the advantages of chitin extraction using the microbial extraction method are as follows:

1. It is homogeneous and prevents deacetylation caused by strong alkali acid, resulting in high-quality products (Ramírez-Coutiño et al., 2006; Zhang et al., 2012).

2. It is an ecofriendly and green method (Sedaghat et al., 2016).

3. It helps in obtaining protein hydrolysate (amino acid and polypeptide) as a byproduct of the deproteination process (Hajji et al., 2015).

\section{Chemical and enzymatic extraction method}

Extraction using the chemical and enzymatic method is a method that has two steps in extraction. The combination of chemicals and enzymes is done to get a shorter extraction time. 
Table 3. $\alpha$-Chitin extraction using microbial fermentation with chitin yield.

\begin{tabular}{|c|c|c|c|c|c|}
\hline No. & Crustacean & Microbial & Fermentation process & Chitin yield (\%) & Reference \\
\hline 1. & $\begin{array}{l}\text { Shrimp (Metapenaeus } \\
\text { monoceros) }\end{array}$ & $\begin{array}{l}\text { Aeribacillus pallidus(VP3), } \\
\text { Lysinibacillus } \\
\text { fusiformis(C250R), and } \\
\text { Anoxybacillus kamchatken sis } \\
\text { (M1V) }\end{array}$ & $\begin{array}{l}\text { Using the Taguchi and Box-Behnken designs, final culture } \\
\text { volume of } 15 \mathrm{ml} \text { with } \mathrm{pH} 9 \text { containing } 20 \mathrm{~g} / \mathrm{l} \text { shrimp powder } \\
\text { and } 10 \mathrm{~g} / 1 \text { sucrose were inoculated with VP } 3, \mathrm{C} 250 \mathrm{R} \text {, and } \\
\mathrm{M} 1 \mathrm{~V} \text { strains at } 0.05,0.1 \text {, and } 0.2 \text {, respectively. The culture } \\
\text { was incubated at } 45^{\circ} \mathrm{C} \text { for } 24 \text { hours under agitation of } 200 \\
\text { rpm }\end{array}$ & 16.7 & (Jabeur et al., 2020) \\
\hline \multirow[t]{4}{*}{2.} & Tiger shrimp head & Brevibacillus parabrevis & \multirow{4}{*}{$\begin{array}{l}\text { Microbial was grown in } 100 \mathrm{ml} \text { of liquid medium containing } \\
3 \%(w / v) \text { shrimp waste, } 0.05 \% \mathrm{MgSO}_{4} \cdot 7 \mathrm{H}_{2} \mathrm{O} \text {, and } 0.1 \% \\
\mathrm{~K}_{2} \mathrm{HPO}_{4} \text {. Incubation conditions were kept at } 37^{\circ} \mathrm{C} \text { and } 150 \\
\text { rpm and the culture was incubated for } 4 \text { days }\end{array}$} & $14.35 \pm 1.40$ & \multirow[t]{4}{*}{ (Thang et al., 2019) } \\
\hline & Tiger shrimp shell & & & $23.23 \pm 3.75$ & \\
\hline & $\begin{array}{l}\text { White leg shrimp } \\
\text { head }\end{array}$ & & & $9.27 \pm 0.20$ & \\
\hline & $\begin{array}{l}\text { White leg shrimp } \\
\text { shell }\end{array}$ & & & $16.87 \pm 3.03$ & \\
\hline \multirow[t]{8}{*}{3.} & \multirow{8}{*}{$\begin{array}{l}\text { Brown crab (Cancer } \\
\text { pagurus) }\end{array}$} & Exiguobacterium spp. & \multirow{8}{*}{$\begin{array}{l}\text { Brown crab shell with } 10 \% \text { glucose sol }(1: 20) \text { was sterilized. } \\
\text { A certain amount of bacterial culture is added and then } \\
\text { incubated for } 5 \text { days at } 30^{\circ} \mathrm{C} \text {. After incubation, the pellet was } \\
\text { washed with deionized water and sterilize with } 70 \%(v / v) \\
\text { ethanol. Referment the previous fermentation results with } \\
10 \% \text { glucose and bacterial inoculum at } 30^{\circ} \mathrm{C} \text { for } 7 \text { days }\end{array}$} & $13.8 \pm 0.85$ & \multirow[t]{8}{*}{ (Harkin et al., 2015) } \\
\hline & & B. licheniformis & & $14.5 \pm .099$ & \\
\hline & & B. subtilis + Lactobacillus spp. & & $14.7 \pm 1.56$ & \\
\hline & & B. cereus + Pseudomonas spp. & & $15.4 \pm 1.56$ & \\
\hline & & $\begin{array}{l}\text { B. cereus }+ \text { Arthrobacter } \\
\text { luteolus }\end{array}$ & & $14.1 \pm 1.41$ & \\
\hline & & Pseudomonas spp. & & $16.3 \pm 0.42$ & \\
\hline & & Pseudomonas migulae & & $15.5 \pm 0.85$ & \\
\hline & & Enterococcus sp. & & $14.6 \pm 1.13$ & \\
\hline \multirow[t]{2}{*}{4.} & \multirow{2}{*}{$\begin{array}{l}\text { Red crab } \\
\text { (Chionoecetes } \\
\text { japonicus) }\end{array}$} & L. paracasei & \multirow{2}{*}{$\begin{array}{l}\text { Crab leg shells with } 10 \% \text { glucose sol and inoculated } \\
\text { microbial was incubated for } 5 \text { days at } 30^{\circ} \mathrm{C} \text {. Pellet was } \\
\text { filtered and washed with distilled water. Pellet was } \\
\text { refermented with } 10 \% \text { glucose soldan microbial at } 30^{\circ} \mathrm{C} \text { in a } \\
\text { shaking incubator }(180 \mathrm{rpm}) \text { for } 7 \text { days }\end{array}$} & $38.67 \pm 1.35$ & \multirow[t]{2}{*}{ (Jung et al., 2007) } \\
\hline & & S. marcescens & & $36.67 \pm 1.33$ & \\
\hline \multirow[t]{3}{*}{5.} & \multirow[t]{3}{*}{$\begin{array}{l}\text { Shrimp (Penaeus } \\
\text { vannamei) }\end{array}$} & Deproteination: S. marcescens & \multirow{3}{*}{$\begin{array}{l}\text { Deproteination: using the Taguchi experimental design, } \\
\text { it was found that the optimal process is obtained with } \\
\text { conditions: } 2 \% \text { shrimp shell, } 2 \text { hours sonication, and } \\
\text { fermentation time with microbial of } 4 \text { daysDemineralization: } \\
\text { the optimal process is obtained with conditions: } 2 \% \text { shrimp } \\
\text { shell, } 15 \% \text { glucose, and fermentation time with microbial of } \\
2 \text { days }\end{array}$} & 18,9 & \multirow[t]{3}{*}{ (Zhang et al., 2012) } \\
\hline & & Demineralization: & & & \\
\hline & & Lactobacillus plantarum & & & \\
\hline 6. & $\begin{array}{l}\text { Crab (Callinectes } \\
\text { bellicosus) }\end{array}$ & Lactobacillus sp. & $\begin{array}{l}\text { Crab shell fermented with microbial in media containing } \\
\text { sugar cane molasses at } 35^{\circ} \mathrm{C} \text { for } 120 \text { hours }\end{array}$ & 34.4 & (Flores-Albino et al., 2012) \\
\hline \multirow[t]{3}{*}{7.} & $\begin{array}{l}\text { Shrimp (Penaeus } \\
\text { monodon) }\end{array}$ & $\begin{array}{l}\text { Deproteination: Bacterium HPl } \\
\text { (culture GM) }\end{array}$ & \multirow{3}{*}{$\begin{array}{l}\text { Deproteination: shrimp shell was fermented in medium } \\
\text { containing P. monodon for } 68 \text { hours and in medium } \\
\text { containing C. crangon for } 50 \text { hours, each at } 37^{\circ} \mathrm{C} \\
\text { Demineralization:deproteination results with glucose } \\
\text { fermented with microbial inoculums at } 37^{\circ} \mathrm{C} \text { for } 47 \text { hours for } \\
\text { P. monodon and } 46 \text { hours for C. crangen }\end{array}$} & 37 & \multirow[t]{3}{*}{ (Xu et al., 2008) } \\
\hline & \multirow{2}{*}{$\begin{array}{l}\text { Shrimp (Crangon } \\
\text { crangon) }\end{array}$} & \multirow{2}{*}{$\begin{array}{l}\text { Demineralization: Lactobacillus } \\
\text { casei MRS1 }\end{array}$} & & 30 & \\
\hline & & & & & \\
\hline 8. & $\begin{array}{l}\text { Crawfish } \\
\text { (Procambarus clarkii) }\end{array}$ & L. paracasei & $\begin{array}{l}\text { Crawfish shell was fermented with } 10 \% \text { dextrose at } 30^{\circ} \mathrm{C} \\
\text { for } 3 \text { days }\end{array}$ & 20.6 & (Cremades et al., 2001) \\
\hline \multirow[t]{3}{*}{9.} & \multirow[t]{3}{*}{ Shrimp } & A. niger0576 & \multirow{3}{*}{$\begin{array}{l}\text { Shrimp shell was fermented with fungi inoculum at } 30^{\circ} \mathrm{C} \\
\text { for } 4 \text { days. Fungal mycelia decanted from shrimp shell. } \\
\text { Entrapped fungal mycelia can release with hot water. } \\
\text { Then, soak the shrimp shell in } 5 \% \text { lithium chloride-N, } \\
\text { N-dimethylacetamide solvent ( } 1: 150) \text { for } 48 \text { hours }\end{array}$} & $22 \pm 2$ & \multirow[t]{3}{*}{ (Teng et al., 2001) } \\
\hline & & A. niger0307 & & $27 \pm 3$ & \\
\hline & & A. niger 0474 & & $17 \pm 3$ & \\
\hline
\end{tabular}

In general, the principle of this method is to replace a microbial in one of the extraction steps with a chemical compound (Table 4).

\section{Natural deep eutectic solvent}

NADES is obtained from an adequate mixture of hydrogen bond acceptor and donor which will enables their bonding through the interaction of hydrogen bonds forming eutectic with a low melting point (Abbott et al., 2004). The advantage of NADES is that it is a nontoxic and biodegradable solvent, where being environmentally friendly which will be an advantage compared to alkaline, acidic, and ionic liquid (IL) solvents (Huang et al., 2018). Besides, NADES can be used in extraction media and as a solvent in several biopolymers, including starch, cellulose, and lignin (Francisco et al., 2012). A mixture of choline halide (chloride/bromide)urea, choline chloride-thiourea, chlorocholine chlorideurea, and betaine hydrochlorideurea is a type of NADES suitable for dissolving $\alpha$-chitin. Dissolution from biopolymers can be carried out using heating under the microwave, conventional heating, or heating by ultrasonication (Sharma et al., 2013). This is appropriate with the data extraction process presented in Table 5. 
Table 4. $\alpha$-Chitin extraction using chemical and enzymatic combination.

\begin{tabular}{|c|c|c|c|c|c|c|c|c|c|c|}
\hline \multirow[b]{2}{*}{ No. } & \multirow[b]{2}{*}{ Crustacean } & \multicolumn{3}{|c|}{ Demineralization } & \multicolumn{3}{|c|}{ Deproteination } & \multirow[b]{2}{*}{ Note } & \multirow[b]{2}{*}{ Chitin yield (\%) } & \multirow[b]{2}{*}{ Reference } \\
\hline & & Solvent $(w / v)$ & Time & $\begin{array}{c}\mathrm{T} \\
\left({ }^{\circ} \mathrm{C}\right)\end{array}$ & Proteinase & Time & $\begin{array}{c}\mathrm{T} \\
\left({ }^{\circ} \mathrm{C}\right)\end{array}$ & & & \\
\hline 1. & Crab (Scylla serrate) & $\begin{array}{l}5 \% \text { glutamic acid } \\
1: 10\end{array}$ & 12 hours & 75 & $\begin{array}{l}\text { Alkaline } \\
\text { protease }\end{array}$ & 6 hours & 55 & $\begin{array}{l}\text { Decolorization } \\
\text { process in } 5 \% \\
(w / v) \text { potassium } \\
\text { permanganate } \\
\text { solution, } 30 \text { minutes, } \\
\text { and continued to soak } \\
\text { in } 3 \% \text { oxalic acid sol }\end{array}$ & 11.88 & $\begin{array}{l}\text { (Ding et al., } \\
\text { 2020) }\end{array}$ \\
\hline 2. & $\begin{array}{l}\text { Crayfish } \\
\text { (Procambarus clarkii) }\end{array}$ & $\begin{array}{l}10 \% \text { innoculation } \\
\text { of Bacillus } \\
\text { coagulans with } \\
5 \%(w / v) \text { glucose } \\
\text { added }\end{array}$ & 48 hours & 50 & $\begin{array}{l}\text { Proteinase K } \\
\text { of } 1,000 \mathrm{U} / \mathrm{g}\end{array}$ & \multicolumn{2}{|c|}{$\begin{array}{l}\text { Demineralization } \\
\text { and deproteination } \\
\text { processes are carried out } \\
\text { simultaneously }\end{array}$} & $\begin{array}{l}\text { DP: } 93 \% \\
\text { DM: } 91 \%\end{array}$ & 94 & $\begin{array}{l}\text { (Dun et al., } \\
\text { 2019) }\end{array}$ \\
\hline 3. & $\begin{array}{l}\text { Blue crab (P. segnis) } \\
\text { Shrimp (P. kerathurus) }\end{array}$ & $\begin{array}{l}\text { Proteinase from } \\
\text { Portunus segnis } \\
\text { viscera }\end{array}$ & 3 hours & 50 & $0.55 \mathrm{M} \mathrm{HCl}$ & 30 minutes & 4 & & $\begin{array}{l}19.06 \pm 1.65 \\
22.23 \pm 0.94\end{array}$ & $\begin{array}{l}\text { (Hamdi et al., } \\
\text { 2017) }\end{array}$ \\
\hline \multirow[t]{2}{*}{4.} & $\begin{array}{l}\text { Shrimp (Metapenaeus } \\
\text { monoceros) }\end{array}$ & $\begin{array}{l}\text { Proteinase from } \\
\text { B. mojavensis }\end{array}$ & 3 hours & 50 & $\begin{array}{l}1.5 \mathrm{M} \mathrm{HCl} \\
1: 10\end{array}$ & 6 hours & 25 & $\mathrm{DP}: 77 \% \pm 3 \%$ & - & $\begin{array}{l}\text { (Younes et al., } \\
\text { 2014) }\end{array}$ \\
\hline & & $\begin{array}{l}\text { Proteinase } \\
\text { from Bacillus } \\
\text { capriscus }\end{array}$ & 3 hours & 45 & & & & DP: $78 \% \pm 2 \%$ & & \\
\hline 5. & $\begin{array}{l}\text { Shrimp (Metapeneaus } \\
\text { monoceros) }\end{array}$ & $\begin{array}{l}\text { A2 crude enzyme } \\
\text { produced by } P \text {. } \\
\text { aeruginosa }\end{array}$ & 3 hours & 40 & $\begin{array}{l}5 \% \mathrm{HCl} \\
(1: 10)\end{array}$ & 6 hours & 25 & DP: $85 \%$ & - & $\begin{array}{l}\text { (Ghorbel- } \\
\text { Bellaaj et al., } \\
\text { 2011) }\end{array}$ \\
\hline 6. & $\begin{array}{l}\text { Shrimp (Metapenaeu } \\
\text { monoceros) }\end{array}$ & $\begin{array}{l}\text { SV1 crude } \\
\text { enzyme by } B . \\
\text { cereus }\end{array}$ & 3 hours & 40 & $\begin{array}{l}1.5 \mathrm{M} \mathrm{HCl} \\
(1: 10)\end{array}$ & 6 hours & 25 & DP: $88 \%$ & $16.55 \pm 1.5$ & $\begin{array}{l}\text { (Manni et al., } \\
\text { 2010) }\end{array}$ \\
\hline
\end{tabular}

*DM $=$ demineralization;

$\mathrm{DP}=$ deproteination .

Table 5. $\alpha$-Chitin extraction using NADES.

\begin{tabular}{|c|c|c|c|c|}
\hline No. & Crustacean & Extraction & Chitin yield (\%) & Reference \\
\hline \multirow[t]{2}{*}{1.} & \multirow[t]{2}{*}{ Shrimp shell } & \multirow{2}{*}{$\begin{array}{l}\text { Choline chloride } 1 \mathrm{M} \text { and malic acids } 1 \mathrm{M}(1: 1) \text { were heated at } 80^{\circ} \mathrm{C} \text {. Shrimp shell and mixture }(1: 20) \\
\text { were heated under microwave for } 9 \text { minutes }\end{array}$} & Chitin: - & (Huang et al., 2018) \\
\hline & & & DM: 99\% DP: $93.8 \%$ & \\
\hline 2. & Lobster Shell & $\begin{array}{l}\text { Choline chloride and malic acid }(1: 2) \text { were heated at } 50^{\circ} \mathrm{C} \text { for } 2 \mathrm{~h} \text {. The proportion of lobster shells and } \\
\text { mixture is }(7: 1) \text {. Decolorization was continued with } 10 \%(\mathrm{w} / \mathrm{v}) \mathrm{H}_{2} \mathrm{O}_{2} \text { at } 80^{\circ} \mathrm{C}\end{array}$ & Chitin: $20.63 \pm 3.30 \%$ & (Zhu et al., 2017) \\
\hline
\end{tabular}

*DM = demineralization;

$\mathrm{DP}=$ deproteination

Table 6. $\alpha$-Chitin extraction using IL.

\begin{tabular}{|c|c|c|c|c|}
\hline No. & Crustacean & Extraction & Chitin yield (\%) & reference \\
\hline 1. & Black tiger Shrimp & $\begin{array}{l}\text { Shrimp shell was suspended with }[\mathrm{C} 2 \mathrm{mim}][\mathrm{OAc}](1: 49) \text {. The mixture was placed into a microwave for } \\
2.5 \text { minutes. The results were centrifuged and washed in DI water. The final result is in filament form }\end{array}$ & 2.5 & (Berton et al., 2018) \\
\hline 2. & Red queen crab & $\begin{array}{l}\text { Crab shell was suspended with 1-allyl-3-methylimidazolium bromide at } 100^{\circ} \mathrm{C} \text { for } 24 \text { hours. The } \\
\text { deproteination product was soaked with } 1.5 \% \mathrm{HCl} \text { for } 3 \text { hours at room temperature }\end{array}$ & 7.5 & (Setoguchi et al., 2012) \\
\hline
\end{tabular}

\section{Ionic liquid}

The IL is a salt with a low boiling point that will form a liquid at temperatures below the water boiling point, which is useful as a solvent for cellulose or other polysaccharides (Zakrzewska et al., 2010). The advantages of the IL method are that it is more economic, efficient, and ecofriendly (Zhu et al., 2017). However, this method also has disadvantages, such as high cost and toxicity (Sharma et al., 2013), besides handling IL by untrained people is also dangerous (Bajaj et al., 2015). Dissolution using IL solvents will damage the hydrogen bonds in the "reassemble" chains into a new arrangement, thus forming amorphous chitin (Shamshina and Rogers, 2020).

\section{Sonication}

It is known that the use of high-intensity ultrasound to extract several polysaccharides requires a short time and little 
solvent so that it will save production costs (Wang and Wang, 2004). However, the addition of sonication to the chitin extraction process is not very useful in the demineralization step; even chitin can be damaged due to some of the material being dissolved and rinsed with reagents due to depolymerization (Kjartansson et al., 2006a). Besides, chitin yields are low due to extensive perforation of the shell (Kjartansson et al., 2006b).

The addition of sonication in extraction will be very useful if there is an incomplete deproteination process. Furthermore, the addition of sonication will also trigger changes in the crystalline chitin form so that it will be easier if it will be reacted chemically (Kjartansson et al., 2006a). Finally, the use of high-intensity ultrasound will be very useful in accelerating the extraction with a low degree of crystalline, if needed (Kjartansson et al., 2006b).

\section{Pilot-scale chitin production}

Chitin production on a pilot scale has been carried out in several experiments (Table 8). Chitin produced at the pilot scale is not very different from chitin production at the laboratory scale. Extraction by bacterial fermentation method is suitable for pilot-scale chitin production; this can be seen in all pilot-scale tests using the microbial method.

\section{Pharmacology activities}

Pharmacological studies of crude $\alpha$-chitin are very rare. Table 9 shows some of the best references we can find. In general, pharmacological activities of $\alpha$-chitin showed its potential to be anticancer and anti-inflammatory and to accelerate wound healing (Anandan et al., 2004; Bae et al., 2013; Teng et al., 2001). Chitin was tested pharmacologically to Hep2 (human larynx carcinoma cell line), RD (human embryo rhabdomyosarcoma cell line), and THP-1 (human monocytic leukemia cell line). Although the cytotoxic effect is not too large, its anticancer potential can be enhanced by changes in the low molecular weight of chitin (Bouhenna et al., 2015; Salah et al., 2013).

Table 7. $\alpha$-Chitin extraction using sonication.

\begin{tabular}{|c|c|c|c|c|c|}
\hline No & Crustacean & Demineralization & Deproteination & Chitin yield (\%) & Reference \\
\hline 1. & Shrimp (Pandalus borealis) & $\begin{array}{l}\text { Shrimp shell was suspended with } 0.25 \mathrm{M} \\
\mathrm{HCl}(1: 40) \text { at } 40^{\circ} \mathrm{C} \text { for } 4 \text { hours; sonication } \\
\text { was added at } 41 \mathrm{~W} / \mathrm{cm}^{2} \text { with temperature } \\
40^{\circ} \mathrm{C} \pm 2^{\circ} \mathrm{C} \text { for } 1 \text { and } 3 \text { hours additional } \\
\text { time }\end{array}$ & $\begin{array}{l}\text { The demineralized product was suspended in } \\
0.25 \mathrm{M} \mathrm{NaOH}(1: 40) \text { at } 40^{\circ} \mathrm{C} \text { with sonication for } \\
4 \text { hours. Additional deproteination is carried out } \\
\text { with soaking to } 1 \mathrm{M} \mathrm{NaOH} \text { for } 2 \text { hours }\end{array}$ & 11.4 & $\begin{array}{l}\text { (Kjartansson et } \\
\text { al., 2006a) }\end{array}$ \\
\hline 2. & $\begin{array}{l}\text { Freshwater Prawn } \\
\text { (Macrobrachium rosenbergii) }\end{array}$ & $\begin{array}{l}\text { Prawn shell was demineralized in } 0.25 \mathrm{M} \\
\mathrm{HCl}(1: 40) \text { for } 4 \text { hours at } 40^{\circ} \mathrm{C} \text { and then } \\
\text { sonicated at } 41 \mathrm{~W} / \mathrm{cm}^{2} \text { for } 4 \text { hours }\end{array}$ & $\begin{array}{l}\text { The demineralization product was soaking with } \\
0.25 \mathrm{M} \mathrm{NaOH}(1: 15) \text { at } 40^{\circ} \mathrm{C} \text { and sonicated for } \\
4 \text { hours. Additional deproteination is carried out } \\
\text { with soaking to } 1 \mathrm{M} \mathrm{NaOH} \text { at } 90^{\circ} \mathrm{C} \text { for } 2 \text { hours }\end{array}$ & 5.03 & $\begin{array}{l}\text { (Kjartansson et } \\
\text { al., 2006b) }\end{array}$ \\
\hline
\end{tabular}

Table 8. Pilot scale of $\alpha$-chitin production.

\begin{tabular}{|c|c|c|c|c|c|c|c|c|c|c|}
\hline \multirow{2}{*}{ No. } & \multirow{2}{*}{ Crustacean } & \multirow{2}{*}{ Scale } & \multicolumn{3}{|c|}{ Deproteination } & \multicolumn{3}{|c|}{ Demineralization } & \multirow{2}{*}{ Chitin yields (\%) } & \multirow{2}{*}{ Reference } \\
\hline & & & Condition & Time & $\mathbf{T}\left({ }^{\circ} \mathrm{C}\right)$ & Condition & Time & $\mathbf{T}\left({ }^{\circ} \mathbf{C}\right)$ & & \\
\hline \multirow[t]{3}{*}{1.} & \multirow[t]{3}{*}{$\begin{array}{l}\text { Shrimp } \\
\text { (Crangon } \\
\text { crangon) }\end{array}$} & 0.251 & $\begin{array}{l}\text { Shrimp shell: glucose, yeast } \\
\text { extract, calcium carbonate } \\
\text { (GYC) medium containing } \\
\text { inoculum }(0.025 \mathrm{~kg}: 0.0251) \\
\text { with } 0.2251 \text { tap water. The } \\
\text { inoculum was obtained from } \\
\text { shrimp shell. Every } 1,500 \mathrm{ml} \\
\text { GYC medium containing } 5 \\
\text { g/l glucose }(\mathrm{G}), 20 \mathrm{~g} / 1 \text { yeast } \\
\text { extract }(\mathrm{Y}) \text {, and } 30 \mathrm{~g} \text { casein }(\mathrm{C})\end{array}$ & $\begin{array}{c}40 \\
\text { hours }\end{array}$ & 37 & $\begin{array}{l}\text { The deproteination } \\
\text { results were fermented } \\
\text { with } 0.0251 \text { lactobacilli } \\
\text { lactic acid with } \\
0.2251 \text { of tap water. } \\
\text { Lactobacilli were grown } \\
\text { in De Man, Rogosa and } \\
\text { Sharpe agar medium } \\
\text { containing different } \\
\text { hexoses and pentoses }\end{array}$ & 40 hours & 37 & 27 & \multirow[t]{3}{*}{$\begin{array}{l}\text { (Bajaj et al., } \\
\text { 2015) }\end{array}$} \\
\hline & & 101 & $\begin{array}{l}\text { Shrimp shell: GYC medium } \\
\text { containing inoculum (1 kg: } 1 \text { 1) } \\
\text { with } 91 \text { tap water }\end{array}$ & $\begin{array}{c}40 \\
\text { hours }\end{array}$ & 37 & $\begin{array}{l}\text { The deproteination } \\
\text { results were fermented } \\
\text { with } 11 \text { of lactobacilli } \\
\text { lactic acid with } 91 \text { of } \\
\text { tap water }\end{array}$ & 40 hours & 37 & 32 & \\
\hline & & 3001 & $\begin{array}{l}\text { Shrimp shell: GYC medium } \\
\text { containing inoculum ( } 39 \mathrm{~kg} \text { : } \\
29 \text { 1) with } 2611 \text { tap water }\end{array}$ & $\begin{array}{c}40 \\
\text { hours }\end{array}$ & 37 & $\begin{array}{l}\text { The deproteinated } \\
\text { product was fermented } \\
\text { with } 291 \text { lactobacilli } \\
\text { lactic acid with } 2711 \\
\text { tap water }\end{array}$ & 40 hours & 37 & 23 & \\
\hline 2. & Shrimp & 201 & $\begin{array}{l}1.2 \mathrm{~kg} \text { shrimp shell fermented } \\
\text { and } 1.21 \mathrm{~B} \text {. cereus } 8 \text { - } 1 \text { strain } \\
\text { culture overnight with added } \\
121 \text { tap water }\end{array}$ & 14 days & 37 & \multicolumn{3}{|c|}{$\begin{array}{l}\text { DP: } 78.6 \pm 2.6 \\
\text { DM: } 73.0 \pm 1.5\end{array}$} & & $\begin{array}{l}\text { (Sorokulova } \\
\text { et al., 2009) }\end{array}$ \\
\hline 3. & $\begin{array}{l}\text { Shrimp } \\
\text { (Penaeus } \\
\text { vannamei) }\end{array}$ & 9301 & $\begin{array}{l}50 \mathrm{~kg} \text { shrimp shell, } 7.5 \mathrm{~kg} \\
\text { glucose, and } 511 \text { of water were } \\
\text { mixed. Then the mixture is } \\
\text { fermented with } L \text {. acidophilus }\end{array}$ & $\begin{array}{c}96 \\
\text { hours }\end{array}$ & 40 & \multicolumn{3}{|c|}{ DP: 90.3} & & $\begin{array}{l}\text { (Duan et al., } \\
\text { 2012) }\end{array}$ \\
\hline
\end{tabular}


Table 9. Pharmacology activities of $\alpha$-chitin.

\begin{tabular}{|c|c|c|c|c|c|}
\hline No. & Crustacean & Chitin obtain & Pharmacological activities & Mechanism & Reference \\
\hline 1. & $\begin{array}{l}\text { Shrimp } \\
\text { (Parapenaeus } \\
\text { longirostris) }\end{array}$ & $\begin{array}{l}\text { Demineralization: the shrimp shell was suspended } \\
\text { with } 2 \mathrm{M} \mathrm{HCl}(1: 15) \text { for } 30 \text { minutes at room } \\
\text { temperature. Deproteination: demineralized } \\
\text { product was soaked with } 2 \mathrm{M} \mathrm{NaOH} \text { for } 90 \\
\text { minutes at } 55^{\circ} \mathrm{C} \text {. } \\
\text { Decolorization: decolorized with } 0.315 \% \mathrm{NaOCl} \\
\text { during } 5 \text { minutes }\end{array}$ & $\begin{array}{l}\text { Chitin has a cytotoxic effect against Hep2 } \\
\text { cells with IC50=400 } \mu \mathrm{g} / \mathrm{ml} \text { and total toxicity } \\
\text { at } 2,000 \mu \mathrm{g} / \mathrm{ml} \text { and RD cell lines with IC } 50= \\
200 \mu \mathrm{g} / \mathrm{ml} \text {; total toxicity is not reached even } \\
\text { at } 300 \mu \mathrm{g} / \mathrm{ml}\end{array}$ & $\begin{array}{l}\text { The interaction between } \\
\text { positive charged group of } \\
\text { chitin and derivative with } \\
\text { negative charge group of } \\
\text { tumor cells }\end{array}$ & $\begin{array}{l}\text { (Bouhenna et } \\
\text { al., 2015) }\end{array}$ \\
\hline 2. & $\begin{array}{l}\text { Shrimp }(P . \\
\text { longirostris })\end{array}$ & $\begin{array}{l}\text { Demineralization: the shrimp shell was suspended } \\
\text { with } 1.5 \mathrm{M} \mathrm{HCl}(1: 15) \text { for } 30 \text { minutes at room } \\
\text { temperature. } \\
\text { Deproteination:demineralized product was soaked } \\
\text { with } 2 \mathrm{M} \mathrm{NaOH} \text { for } 120 \text { minutes at } 45^{\circ} \mathrm{C} \text {. } \\
\text { Low molecular chitin preparation: chitin was } \\
\text { hydrolyzed with } 7 \mathrm{~N} \mathrm{HCl} \text { at } 70^{\circ} \mathrm{C} \text { for } 3 \text { hours }\end{array}$ & $\begin{array}{l}\text { Chitin has the potential to be a specific } \\
\text { anticancer on the human monocytic leukemia } \\
\text { cell line, THP-1. However, the potential is not } \\
\text { greater than the low molecular chitin }\end{array}$ & $\begin{array}{l}\text { Possible mechanism based } \\
\text { on the presence of chitin- } \\
\text { binding protein (maybe } \\
\text { YKL-40), also known as } \\
\text { chitinase. This bond is } \\
\text { shown by the expression } \\
\text { of THP-1 cells and the } \\
\text { unexpression of MRC-5 } \\
\text { cells due to binding to chitin. } \\
\text { This interaction will inhibit } \\
\text { the growth of tumor cells }\end{array}$ & $\begin{array}{l}\text { (Salah et al., } \\
\text { 2013) }\end{array}$ \\
\hline 3. & Alpha chitin & $\alpha$-Chitin with diameter particle average $11.0 \mu \mathrm{m}$ & $\begin{array}{l}\text { Giving food containing } 0.2 \% \alpha \text {-chitin in mice } \\
\text { can reduce peanut allergy in mice better than } \\
\beta \text {-chitin and } \beta \text {-chitosan at the same dose. } \\
\text { Chitin has IgE protection which will mediate } \\
\text { anaphylaxis. Additionally, chitin inhibits the } \\
\text { Th2 response thereby reducing the incidence } \\
\text { of inflammation }\end{array}$ & $\begin{array}{l}\text { Increase levels of IL-12, } \\
\text { where IL-12 will stimulate } \\
\text { Th1 cells to produce IFN- } \\
\text { gamma, thus producing } \\
\text { IL-12 which will strongly } \\
\text { suppress the production } \\
\text { of IgE }\end{array}$ & $\begin{array}{l}\text { (Bae et al., } \\
\text { 2013) }\end{array}$ \\
\hline 4. & Shrimp & Shown in Table 3 no. 9 & $\begin{array}{l}\text { Chitin was tested on fibroblast cell lines from } \\
\text { mouse and human and osteoblast cell lines for } \\
4 \text { days using tetrazolium colorimetric based } \\
\text { (3-[4,5-dimethylthiazolyl-2]-2,-diphenyl } \\
\text { tetrazolium bromide assay) and neutral red } \\
\text { uptake assays. The results show that there are no } \\
\text { acute cytotoxicty and proproliferation effects }\end{array}$ & - & $\begin{array}{l}\text { (Teng et al., } \\
\text { 2001) }\end{array}$ \\
\hline 5. & Prawn & Kitin (MW $1.08 \times 10^{5} \mathrm{KDa}$; purity $97.2 \%$ ) & $\begin{array}{l}\text { Giving food containing } 2 \% \text { chitin in rats for } \\
30 \text { days showed effectiveness in preventing } \\
\text { gastric ulcer induced by } \mathrm{HCl}+\text { ethanol }\end{array}$ & $\begin{array}{l}\text { Chitin administration will } \\
\text { reduce lipid peroxidation } \\
\text { and increase the activity of } \\
\text { antiperoxidation enzymes } \\
\text { and glutathione-dependent } \\
\text { antioxidant enzymes }\end{array}$ & $\begin{array}{l}\text { (Anandan et al., } \\
\text { 2004) }\end{array}$ \\
\hline
\end{tabular}

\section{CONCLUSION}

There are several methods to extract $\alpha$-chitin from crustaceans, that is, chemical, microbiological, chemical-enzymatic combination, using NADES, IL solvent, and sonication. The best $\alpha$-chitin extraction method from crustaceans is the chemical 1enzymatic combination method. This method was able to provide more efficient extraction time and is environmentally friendly with quality parameters, such as very good and consistent deproteination and demineralization. In addition, the chitin yield was better than that of other methods. Followed by successive recommended methods were the microbiological methods, NADES, chemical methods, and IL, respectively. $\alpha$-Chitin has proven to possess anticancer and antiinflammatory potential and could accelerate wound healing. The mechanism of action of $\alpha$-chitin anti-inflammatory activity is still interesting to be further explored.

\section{CONFLICTS OF INTEREST}

All the authors declare that they have no conflicts of interest for this work.

\section{FUNDING}

None.

\section{REFERENCES}

Abbott AP, Boothby D, Capper G, Davies DL, Rasheed RK. Deep eutectic solvents formed between choline chloride and carboxylic acids: versatile alternatives to ionic liquids. J Am Chem Soc, 2004; 126(29):9142-7.
Agboh OC, Qin Y. Chitin and chitosan fibers. Polym Adv Technol, 1997; 8:355-65.

Akpan EI, Gbenebor OP, Adeosun SO. Synthesis and characterisation of chitin from periwinkle (Tympanotonus fusatus (L.)) and snail (Lissachatina fulica (Bowdich)) shells. Int J Biol Macromol, 2018; 106:1080-88.

Anandan R, Nair PGV, Mathew S. Anti-ulcerogenic effect of chitin and chitosan on mucosal antioxidant defence system in HCl-ethanolinduced ulcer in rats. J Pharm Pharmacol, 2004; 56(2):265-9.

Aranaz I, Mengíbar M, Harris R, Paños I, Miralles B, Acosta N, Heras Á. Functional characterization of chitin and chitosan. Curr Chem Biol, 2009; 3:203-30.

Arbia W, Adour L, Amrane A, Lounici H. Optimization of medium composition for enhanced chitin extraction from Parapenaeus longirostris by Lactobacillus helveticus using response surface methodology. Food Hydrocoll, 2013; 3:392-403.

Bae, MJ, Shin HS, Kim EK, Kim J, Shon DH. Oral administration of chitin and chitosan prevents peanut-induced anaphylaxis in a murine food allergy model. Int J Biol Macromol, 2013; 61:164-8.

Bajaj M, Freiberg A, Winter J, Xu Y, Gallert C. Pilot-scale chitin extraction from shrimp shell waste by deproteination and decalcification with bacterial enrichment cultures. Appl Microbiol Biotechnol, 2015; 99(22):9835-46.

Bernabé P, Becherán L, Cabrera-barjas G, Nesic A, Alburquenque C, Tapia CV, Ríos PDL. Chilean crab (Aegla cholchol) as a new source of chitin and chitosan with antifungal properties against Candida spp. Int J Biol Macromol, 2020; 149:962-74.

Berton P,Shamshina JL, Ostadjoo S, King CA, Rogers RD. Enzymatic hydrolysis of ionic liquid-extracted chitin. Carbohydr Polym, 2018; 199:228-35.

Bouhenna M, Salah R, Bakour R, Drouiche N, Abdi N, Grib H, Mameri N. Effects of chitin and its derivatives on human cancer cells lines. Environ Sci Pollut Res Int, 2015; 22(20):15579-86. 
Cremades O, Ponce E, Corpas R, Gutierrez J, Jover M, AlvarezOssorio M, Bautista Palomas JD. Processing of crawfish (Procambarus clarkii) for the preparation of carotenoproteins and chitin. J Agric Food Chem, 2001; 49:5468-72.

de Coninck J, Bouquelet S, Dumortier V, Duyme F, VerdierDenantes I. Industrial media and fermentation processes for improved growth and protease production by Tetrahymena thermophila BIII. J Ind Microbiol Biotechnol, 2000; 24(4):285-90.

Ding H, Lv L, Wang Z, Liu L. Study on the "Glutamic AcidEnzymolysis" process for extracting chitin from crab shell waste and its by-product recovery. Appl Biochem Biotechnol, 2020; 190(3):1074-91.

Duan S, Li L, Zhuang Z, Wu W, Hong S, Zhou J. Improved production of chitin from shrimp waste by fermentation with epiphytic lactic acid bacteria. Carbohydr Polym, 2012; 89(4):1283-8.

Dun Y, Li Y, Xu J, Hu Y, Zhang C, Liang Y, Zhao S. Simultaneous fermentation and hydrolysis to extract chitin from crayfish shell waste. Int $\mathrm{J}$ Biol Macromol, 2019; 123:420-6.

FAO. 2020. FAO global aquaculture production volume and value statistics. Available via: http://fao.org/figis/servlet/tabselector (Accessed 8 May 2020).

Flores-Albino B, Arias L, Gómez J, Castillo A, GimenoM, Shirai $\mathrm{K}$. Chitin and $\mathrm{L}(+)$-lactic acid production from crab (Callinectes bellicosus) wastes by fermentation of Lactobacillus sp. B2 using sugar cane molasses as carbon source. Bioprocess Biosyst Eng, 2012; 35(7):1193-200.

Francisco M, van den Bruinhorst A, Kroon MC. New natural and renewable low transition temperature mixtures (LTTMs): screening as solvents for lignocellulosic biomass processing. Green Chem, 2012; 14(8):2153-7.

Gamal RF, El-Tayeb TS, Raffat EI, Ibrahim HMM, Bashandy AS. Optimization of chitin yield from shrimp shell waste by Bacillus subtilis and impact of gamma irradiation on production of low molecular weight chitosan. Int J Biol Macromol, 2016; 91:598-608.

Ghorbel-Bellaaj O, Hajji S, Younes I, Chaabouni M. Optimization of chitin extraction from shrimp waste with Bacillus pumilus A1 using response surface methodology. Int J Biol Macromol, 2013; 61:243-50.

Ghorbel-Bellaaj O, Hmidet N, Jellouli K, Younes I, Maâlej H, Hachicha R, Nasri M. Shrimp waste fermentation with Pseudomonas aeruginosa A2: optimization of chitin extraction conditions through Plackett-Burman and response surface methodology approaches. Int J Biol Macromol, 2011a; 48(4):596-602.

Ghorbel-Bellaaj O, Jellouli K, Younes I, Manni L, Ouled Salem M, Nasri, M. A solvent-stable metalloprotease produced by Pseudomonas aeruginosa A2 grown on shrimp shell waste and its application in chitin extraction. Appl Biochem Biotechnol, 2011b; 164(4):410-25.

Ghorbel-Bellaaj O, Younes I, Maâlej H, Hajji S, Nasri M. Chitin extraction from shrimp shell waste using Bacillus bacteria. Int J Biol Macromol, 2012; 51(5):1196-201.

Goodrich JD, Winter WT. $\alpha$-chitin nanocrystals prepared from shrimp shells and their specific surface area measurement Biomacromolecules, 2007; 8(1):252-7.

Hajji S, Ghorbel-Bellaaj O, Younes I, Jellouli K, Nasri M. Chitin extraction from crab shells by Bacillus bacteria. Biological activities of fermented crab supernatants. Int J Biol Macromol, 2015; 79:167-73.

Hamdi M, Hammami A, Hajji S, Jridi M, Nasri R. Chitin extraction from blue crab (Portunus segnis) and shrimp (Penaeus kerathurus) shells using digestive alkaline proteases from $P$. segnis viscera. Int J Biol Macromol, 2017; 101:455-63.

Harkin C, Brück WM, Lynch C. Isolation \& identification of bacteria for the treatment of brown crab (Cancer pagurus) waste to produce chitinous material. J Appl Microbiol, 2015; 118(4):954-65.

Hassainia A, Satha H, Boufi S. Chitin from agaricus bisporus: extraction and characterization. Int J Biol Macromol, 2018; 117:1334-42.

Huang WC, Zhao D, Guo N, Xue C, Mao X. Green and facile production of chitin from crustacean shells using a natural deep eutectic solvent. J Agric Food Chem, 2018; 66(45):11897-901.

Ifuku S, Nogi M, Abe K, Yoshioka M, Morimoto M, Saimoto H, Yano H. Preparation of chitin nanofibers with a uniform width as $\alpha$-chitin from crab shells. Biomacromolecules, 2009; 10(6):1584-8.

Jabeur F, Mechri S, Kriaa M, Gharbi I, Bejaoui N, Sadok S, Jaouadi B. Statistical experimental design optimization of microbial proteases production under co-culture conditions for chitin recovery from speckled shrimp metapenaeus monoceros by-product. Biomed Res Int, 2020; 2020:1-10

Jollès P, Muzzarelli RA. Chitin and chitinases vol.87. Birkhäuser Verlag.EXS (Basel), Basel, Switzerland,

Jung HS, Kim MH, Shin JY, Park SR, Jung JY, Park WH Electrospinning and wound healing activity of $\beta$-chitin extracted from cuttlefish bone. Carbohydr Polym, 2018; 193: 205-11.

Jung WJ, Jo GH, Kuk JH, Kim KY, Park RD. Extraction of chitin from red crab shell waste by cofermentation with Lactobacillus paracasei subsp. tolerans KCTC-3074 and serratia marcescens FS-3. Appl Microbiol Biotechnol, 2006; 71(2):234-7.

Jung WJ, Jo GH, Kuk JH, Kim YJ, Oh KT, Park RD. Production of chitin from red crab shell waste by successive fermentation with Lactobacillus paracasei KCTC-3074 and Serratia marcescens FS-3. Carbohydr Polym, 2007; 68(4):746-50.

Kaya M, Karaarslan M, Baran T, Can E, Ekemen G, Bitim B, Duman F. The quick extraction of chitin from an epizoic crustacean species (Chelonibia patula). Nat Prod Res, 2014; 28(23):2186-90.

Kjartansson GT, Zivanovic S, Kristbergsson K, Weiss J. Sonication-assisted extraction of chitin from North Atlantic Shrimps (Pandalus borealis). J Agric Food Chem, 2006a; 54(16):5894-902.

Kjartansson GT, Zivanovic S, Kristbergsson K, Weiss J. Sonication-assisted extraction of chitin from shells of fresh water prawns (Macrobrachium rosenbergii). J Agric Food Chem, 2006b; 54(9): 3317-23.

Manni L, Ghorbel-Bellaaj O, Jellouli K, Younes I, Nasri M. Extraction and characterization of chitin, chitosan, and protein hydrolysates prepared from shrimp waste by treatment with crude protease from Bacillus cereus SV1. Appl Biochem Biotechnol, 2010; 162(2):345-57.

Mao X, Zhang J, Kan F, Gao Y, Lan J, Zhang X, Lin H Antioxidant production and chitin recovery from shrimp head fermentation with Streptococcus thermophilus. Food Sci Biotechnol, 2013; 22:1023-32.

Maruthiah T, Palavesam A. Characterization of haloalkalophilic organic solvent tolerant protease for chitin extraction from shrimp shell waste. Int J Biol Macromol, 2017; 97.

Mathur NK, Narang CK. Chitin and chitosan, versatile polysaccharides from marine animals. J Chem Educ, 1990; 67(11):938-42.

Mohan K, Ravichandran S, Muralisankar T, Uthayakumar V, Chandirasekar R, Rajeevgandhi C, Seedevi P. Extraction and characterization of chitin from sea snail Conus inscriptus (Reeve, 1843). Int J Biol Macromol, 2019; 126:555-60.

Oh KT, Kim YJ, NguyenVN, Jung WJ, Park RD. Demineralization of crab shell waste by Pseudomonas aeruginosa F722. Process Biochem, 2007; 42(7):1069-74.

Ordóñez-Del Pazo T, Antelo LT, Franco-Uría A, Pérez-Martín RI, Sotelo CG, Alonso AA. Fish discards management in selected Spanish and Portuguese métiers: identification and potential valorisation. Trends Food Sci Technol, 2014; 36(1):29-43.

Pacheco N, Garnica-Gonzalez M, Gimeno M, Bárzana E, Trombotto S, David L, Shirai K. Structural characterization of chitin and chitosan obtained by biological and chemical methods. Biomacromolecules, 2011; 12(9):3285-90.

Percot A, Viton C, Domard A. Optimization of chitin extraction from shrimp shells. Biomacromolecules, 2003; 4(1):12-8.

Ramírez-Coutiño L, Marín-Cervantes $M$ del C, Huerta S, Revah S, Shirai K. Enzymatic hydrolysis of chitin in the production of oligosaccharides using Lecanicillium fungicola chitinases. Process Biochem, 2006; 41(5):1106-10.

Rinaudo M. Chitin and chitosan: properties and applications. Prog Polym Sci, 2006; 31(7):603-32.

Roy JC, Salaün F, Giraud S, Ferri A. Solubility of chitin: solvents, solution behaviors and their related mechanisms. In Solubility of polysaccharides an. pp 109-26, 2017. 
Salah R, Michaud P, Mati F, Harrat Z, Lounici H, Abdi N, Mameri $\mathrm{N}$. Anticancer activity of chemically prepared shrimp low molecular weight chitin evaluation with the human monocyte leukaemia cell line, THP-1. Int J Biol Macromol, 2013; 52:333-9.

Sedaghat F, Yousefzadi M, Toiserkani H, Najafipour S. Chitin from Penaeus merguiensis via microbial fermentation processing and antioxidant activity. Int J Biol Macromol, 2016; 82:279-83.

Setoguchi T, Kato T, Yamamoto K, Kadokawa J. Facile production of chitin from crab shells using ionic liquid and citric acid. Int $\mathrm{J}$ Biol Macromol, 2012; 50(3):861-4.

Shamshina J, Rogers R. Are ionic liquids enabling technology? Startup to Scale-Up to Find Out. pp 69-85, 2020.

Sharma M, Mukesh C, Mondal D, Prasad K. Dissolution of $\alpha$-chitin in deep eutectic solvents. RSC Adv, 2013; 3 .

Sorokulova I, Krumnow A, Globa L, Vodyanoy V. Efficient decomposition of shrimp shell waste using Bacillus cereus and Exiguobacterium acetylicum. J Ind Microbiol Biotechnol, 2009; 36:1123-6.

Tarusin DN, Bazhenov VV, Schütz K, Brüggemeier S, Gossla E, AkkineniAR, Ehrlich H. Novel chitin scaffolds derived from marine sponge Ianthella basta for tissue engineering approaches based on human mesenchymal stromal cells: biocompatibility and cryopreservation. Int J Biol Macromol, 2017; 104:1955-65.

Teng WL, Khor E, Tan TK, Lim LY, Tan SC. Concurrent production of chitin from shrimp shells and fungi. Carbohydr Res, 2001; 332(3):305-16.

Thang C, Ngoc T, Nguyen VB, Phuong T, Vo K. Chitin extraction from shrimp waste by liquid fermentation using an alkaline protease-producing strain, Brevibacillus parabrevis. Int J Biol Macromol, 2019; 131:706-15.

Vani R, Amalan Stanley S. Studies on the extraction of chitin and chitosan from different aquatic organisms. Adv Bio Tech, 2013; 12:12-5.

Wang L, Wang YJ. Application of high-intensity ultrasound and surfactants in rice starch isolation. Cereal Chem, 2004; 81(1):140-4.

Wang SL, Kao TY, Wang CL, Yen YH, Chern MK, Chen YH. A solvent stable metalloprotease produced by Bacillus sp. TKU004 and its application in the deproteinization of squid pen for $\beta$-chitin preparation. Enzyme Microb Technol, 2006; 39(4):724-31.
Wang Y, Chang Y, Yu L, Zhang C, Xu X, Xue Y, Xue C. Crystalline structure and thermal property characterization of chitin from Antarctic krill (Euphausia superba). Carbohydr Polym, 2013; 92(1):90-7.

Wu Q, Mushi NE, Berglund LA. High-strength nanostructured films based on well-preserved $\alpha$-chitin nanofibrils disintegrated from insect cuticles. Biomacromolecules, 2020; 21(2):604-12.

$\mathrm{Xu}$ Y, Gallert C, Winter J. Chitin purification from shrimp wastes by microbial deproteination and decalcification. Appl Microbiol Biotechnol, 2008; 79(4):687-97.

Younes I, Ghorbel-Bellaaj O, Nasri R, Chaabouni M, Rinaudo M, Nasri M. Chitin and chitosan preparation from shrimp shells using optimized enzymatic deproteinization. Process Biochem, 2012; 47(12):2032-9.

Younes I, Hajji S, Frachet V, Rinaudo M, Jellouli K, Nasri M. Chitin extraction from shrimp shell using enzymatic treatment. Antitumor, antioxidant and antimicrobial activities of chitosan. Int J Biol Macromol, 2014; 69:489-98.

Zakrzewska ME, Bogel-Łukasik E, Bogel-Łukasik R. Solubility of carbohydrates in ionic liquids. Energy Fuels, 2010; 24(2):737-45.

Zhang H, Jin Y, Deng Y, Wang D, Zhao Y. Production of chitin from shrimp shell powders using Serratia marcescens B742 and Lactobacillus plantarum ATCC 8014 successive two-step fermentation. Carbohydr Res, 2012; 362:13-20.

Zhu P, Gu Z, Hong S, Lian H. One-pot production of chitin with high purity from lobster shells using choline chloride-malonic acid deep eutectic solvent. Carbohydr Polym, 2017; 177:217-23.

How to cite this article:

Amelia R, Saptarini NM, Halimah E, Andriani Y, Hasanah AN, Levita J, Sumiwi SA. Pharmacology activities and extraction of $\alpha$-chitin prepared from crustaceans: A review. J Appl Pharm Sci, 2020; 10(12):140-149. 